Journal of K6, Education, and Management (J-K6EM)

Vol. 2, No. 2, 20I9, pp. II2-I I7. ISSN 2580-2I35

\title{
Madrasah Management Based on Stock (Case Study in Madrasah Aliyah Darul Amien Tabuk Labak and Madrasah Aliyah One Roof Al Azhar Kandangan Hulu Sungai District Selatan)
}

\author{
${ }^{1}$ Wahyu, $\mathrm{H},{ }^{2}$ Armiati, ${ }^{3}$ Karyono Ibnu Ahmad \\ ${ }^{1}$ Graduate Program of Education Management, Universitas Lambung Mangkurat, Banjarmasin, Indonesia \\ ${ }^{2}$ Graduate Program of Early Childhood Education, Universitas Lambung Mangkurat, Banjarmasin, Indonesia
}

\begin{tabular}{|c|c|}
\hline ARTICLE INFO & A B S T R A C T \\
\hline \multirow[t]{2}{*}{$\begin{array}{l}\text { Article history } \\
\text { Received: June } \\
\text { Revised: August } \\
\text { Accepted: September } \\
\text { Keywords: Islamic boarding } \\
\text { school, madrasah aliyah, cottage } \\
\text { for school, curriculum } \\
\text { management }\end{array}$} & 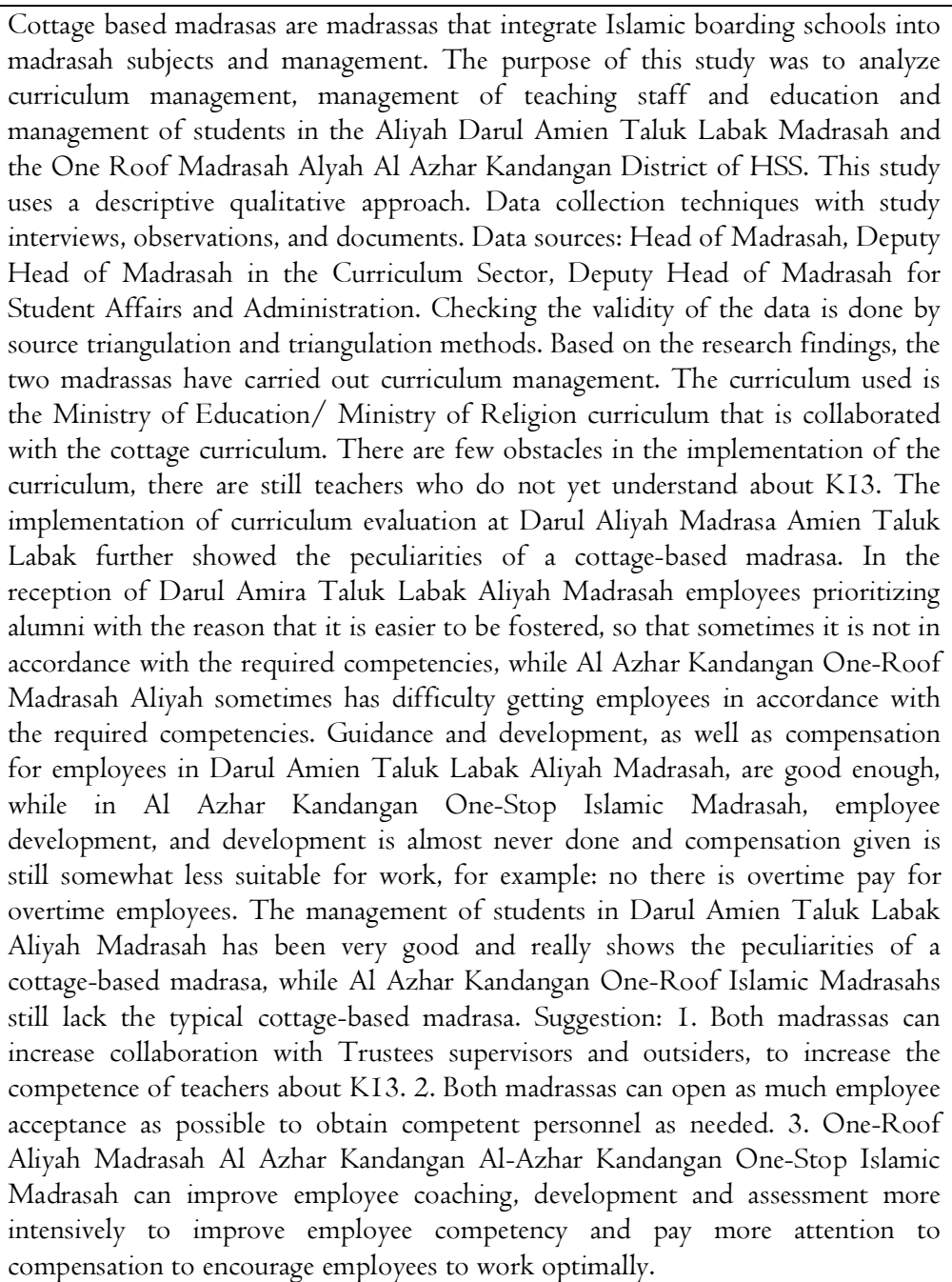 \\
\hline & 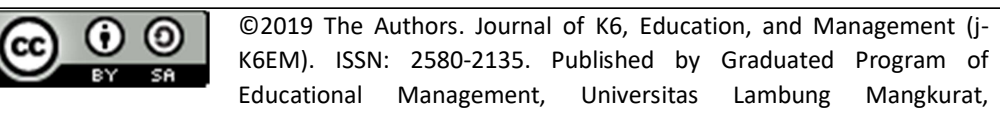 \\
\hline
\end{tabular}




\section{Introduction}

Based on the Law on management law products, namely the National Education System Law Article 35 Paragraph I explains that the process of administering education refers to the standards of content, process, competency of graduates, education personnel, infrastructure, financing and assessment of education which must be planned and periodically. Therefore, to achieve the objectives of an effective and efficient national education standard, it is necessary to have planned, directed and systematic management (Kardata et al., 2018). School-based management is a strategy to realize effective and productive schools (Aslamiah, 2015). School-based management is a new paradigm of education management, which provides broad autonomy to schools, and community involvement within the framework of national education policies (Suriansyah, Aslamiyah \& Sulaiman, 20I4). Autonomy is given so that schools are free to manage resources, sources of funds, learning resources and allocate them according to priorities, and are more responsive to local needs, (Suahimi \& Efendi, 20I8).

The hut comes from the word fundus which means hotel or hostel. The lodge functions as a dormitory for santri. The lodge is a characteristic of the pesantren tradition that distinguishes it from the traditional education system in mosques that develops in most Islamic regions of other countries (Mustari, Muliawan, 2005).

Cottage means a house or a simple residence made of bamboo, which is a simple shelter for students who are far from their origin. Aside from being a place to live in the cottage, it is also intended to follow the lessons given by the scholars, as a place of training or training for students to be able to live independently in the Nata community 200I (Nata, 200I).

Based on the word base or can be interpreted with a basis. Madrasa or Islamic boarding school is an educational institution or place for the ongoing educational process. Pondok/ Pesantren Based Education is a tool that serves as a set of organizations created to achieve educational goals that take place in boarding schools (Halim, 2005).

Islamic Boarding School is one of the social facts, which arises because of human consciousness, the results of thoughts, discussions between institutions in this case the Ministry of Religion, Ministry of National Education, Center for Educational Development (CERDEV) UIN Syarif Hidayatullah Jakarta, Islamic Boarding Schools, and School (Ritzer, 2004).

In general, the term management can be assumed as management, both management in the individual context and institutional context (Suriansyah, 2018). Islamic boarding schools are one of the educational institutions that need systematic and professional management (Kardata et al., 20I8). This is done because many Islamic boarding schools are currently developing, but the management system that is implemented is still not maximal (Alamsyah et al., 2019). Implementation of management education in madrasas plays a role in helping madrasah management tasks, starting from the planning process, organizing, actuating, to controlling (supervision), useful and has real value that can be felt when that too and in the future, supports operational, managerial and strategic activities of the organization by utilizing various existing resources and the availability of sharing functions to achieve the desired goals (Normianti et al., 2019).

The implementation of education management in the Aliayah Darul Amien Taluk Labak Madrasah and the One-Roof Al Azhar Kandangan Madrasah Aliyah is expected to provide good services for stakeholders which ultimately have an impact on improving the results or achievements of the implementation of learning and graduates (Rahmani et al., 2019).

Thus, Islamic boarding schools are nonformal educational institutions that must have special attention in the field of education and development of science in order to realize effective and efficient learning goals based on good management.

\section{Methodology}

The research uses qualitative descriptive method. Qualitative research is research that intends to understand the phenomenon of what is experienced by research subjects, such as behavior, perception, motivation, action, etc., holistically and with descriptions in the form of words and languages in a special context that is natural by utilizing scientific method (Koening \& Samuel, 1957) Descriptive research method is research that aims to describe or explain something as it is and this method allows researchers to choose the object of research to be studied in depth rather than just making a general map of the object of research (Irwan, 2003).

The reason the author uses qualitative methods, where the author immediately becomes a key instrument that plunges into location to obtain the necessary data, then analyzes and draws on results or conclusions relating to the management of cottagebased madrasa in Darul Amien Taluk Labak Madrasas and Al Roof One Madrasah Aliyah Azhar Kandangan, Hulu Sungai Selatan Regency in the form of 
interpretations from the researcher towards this behavior.

The data obtained in the field, both from the results of interviews, observations and documents so much that it needs to be reduced is summarized and selected in the main and in accordance with the focus of the study, then arranged systematically so as to provide a clear picture of the results of the study. Data collection is done by interview techniques, observation, and documentation (Sahrudin et al., 2019). Data sources: Head of Madrasah, Deputy Head of Madrasah in the Curriculum Sector, Deputy Head of Madrasah for Student Affairs and Administration

The data in the field were recorded in the form of descriptive field notes about what was seen, heard, or felt by the research subjects. Checking the validity of the data is done by source triangulation and triangulation methods

\section{Findings and Discussion}

Madrasah Management based on Islamic boarding schools on Aliyah Darul Amien Taluk Labak and One-Roof Al Azhar Kandangan Madrasah Aliyah.

\section{A. Curriculum Management}

a. Planning curriculum

Curriculum planning such as making I

KTSP document, making subject matter analysis, making effective weeks calculations, compiling preentries, compiling procedures and making lesson plans have been done in both of these madrasas.

b. Implementation of the curriculum

There are few obstacles in the implementation of the curriculum because there are still many teachers who do not yet understand KI3, although they continue to strive to provide quality education services, and have the opportunity to express themselves freely, dynamically and pleasantly.

c. Curriculum Supervision

The Darulah Aliyah Madrasa Amien Taluk Labak has carried out integrated supervision between the head of the madrasa, supervisors, and foundations, while the One-Roof Al Azhar Madrasah Aliyah is only carried out by the madrasa supervisor.

d. Curriculum Evaluation

Curriculum evaluation in Darul Amien Taluk Labak Aliyah Madrasah in addition to doing PAS like madrasa in general, they also do PAS in a typical cottage way, whereas PAS in Al Azhar Kandangan One-Roof Aliyah Madrasah is the same as PAS conducted by madrasas in general, there is no specificity of a madrasa cottage based.

\section{B. Management of Educators and Education Staff}

a. Planning

The planning of educators and education in both madrasas is almost the same, namely paying attention to the needs needed. Only the difference in Madrasalah Aliyah Darul Amien Taluk Labak prioritizes accepting its alumni, while in the One-Roof Aliyah Madrasah Al Azhar Kandangan is open to the public.

In accordance with the theory put forward by F. Sikula that planning is the process of determining labor requirements and how to meet these needs to implement an integrated plan of the organization has been carried out by these two madrasas even though in different ways

b. Selection

Selection is a decision-making process in which individuals are chosen to fill a position based on an assessment of the characteristics of the individual concerned, according to what is required by the position. In both madrassas this cannot be done for different reasons. In Madrasah Aliyah Darul Amien Taluk Labak, as explained above, prioritizes alumni, while Al Azhar Kandangan One-Stop Madrasah Aliyah, it is difficult to get an appropriate guardian/educator.

c. Coaching and Development

The development or development of education personnel is an effort to utilize, advance and improve the work productivity of each educational staff that exists throughout all levels of organizational management and education levels (madrasas). The purpose of this coaching activity is the growth of the ability of each educational staff which includes scientific growth, insight into the thinking, attitudes towards their work, and skills in carrying out their daily tasks so that work productivity can be improved.

d. Assessment

Educational staff assessment is an effort that is carried out to find out how well the performance of someone in the teaching staff performs their work duties and how much potential they have to develop. Madrasah Aliyah Darul Amien Taluk Labak has made an assessment by making notes that will be discussed at the weekly meeting, on Friday night. Whereas the One Roof Madrasah Aliyah Al Azhar Kandangan has not yet made an assessment.

e. Compensation

Compensation has been given in both madrasas, except that the compensation in Al Azhar Kandangan One-Stop Islamic Madrasah is still lacking, while compensation in Madrasalah Aliyah Darul Amien Taluk Labak is sufficient to pay attention to the welfare of its employees.

\section{f. Stop}

Dismissal of education personnel is a process that makes a person an education staff unable to carry out work duties or job functions both temporarily and forever. There are many reasons that cause someone to quit the job (dropping out of work). Both in the Aliyah Darul Amien Taluk Labak Madrasah and the Al Azhar Kandangan One-Roof Islamic School, there has never been a dismissal of staff/educators by the madrasa. So far, employees/educators have stopped on their own accord for various reasons, such as moving a 
place of residence, working in another city, or being appointed as a civil servant.

\section{Student Management}

From the results of interviews, observations and documents, it is known that the management of students in the Aliyah Darul Amien Taluk Labak Madrasah and in the One Roof Madrasah Al Azhar Kandangan starts from: analyzing the needs of students, recruitment, selection, orientation, class distribution, coaching and development, recording, reporting, graduation to alumni.

a. Student Needs Analysis

Both at the Darul Amien Taluk Labak Aliyah Madrasah and at the Al Azhar Kandangan One-Stop Madrasah Aliyah, making student admission planning adjusted to capacity, a little difference in the Darul Amien Taluk Labak Aliyah Madrasah with at the Al Azhar Kandangan One-Roof Madrasah in Darul Amira Taluk Labak Aliyah Madrasah requires students in the previous level to become students at the aliyah level and require intensive classes for students who come from outside the hut to adjust to cottage lessons. All students are required to stay, so the atmosphere of the cottage-based madrasa is more pronounced, while in the One-Roof Al Azhar Kandangan Madrasah Aliyah, it does not require students in the previous level to be aliyah and there is no obligation for all students, only those I just want to go home so that the atmosphere of the cottage-based madrasa is not very visible. From the findings above, it is known that in Darul Aliyah Madrasa Amien Taluk Labak, the planning of student acceptance is good, in accordance with the existing theory, where the planning of student admission is adjusted to the available capacity.

b. Recruitment

The recruitment of students in both madrasas starts with the formation of a new prospective student admission committee to become new students, only the difference, the announcement of new student admissions at the One Atap Al Azhar Islamic Senior High School Kandangan is only installed at the madrasa gate for reasons of fear if too many register, so that it exceeds capacity. Whereas in Darul Amien Taluk Labak Aliyah Madrasah, announcements are disseminated to schools such as SMP / MTs but are not as intense as they already have prospective students in the hut.

Recruitment of students in both madrassas is also in accordance with the existing theories, namely together starting with the formation of a new student admissions committee and posting announcements, both of them are not keen to make acceptance announcements but with slightly different reasons, Darul Aliyah Madrasa Amien Taluk Labak already have prospective new students who come from the cottage alumni at the previous level, who can immediately become new students who already have knowledge of cottage subjects, and if accepting students from outside their hut they must provide intensive / class equivalence classes with subjects the cottage, while the One Roof Madrasah Aliyah Al Azhar Kandangan has the reason to fear most applicants for new students outside the available capacity. It is recommended that registration be opened as widely as possible, then the selection is made and accepted according to capacity.

\section{c. Selection}

Selection of new student admissions generally by: I) through tests or tests, namely psychological tests, physical tests, medical tests, academic tests, or skills tests; 2) through tracing talents and abilities, usually based on achievements achieved by prospective students in the field of sports or the arts; 3) based on the value of the STTB or UN.

The two madrassas have a somewhat different selection method, where the way they select shows the characteristics of a madrasa. Selection conducted by Darul Aliyah Madrasa Amien Taluk Labak has shown that this madrasa is a cottage-based madrasa, where the method of selection is interviewing prospective students and parents/guardians of students to find out their sincerity to study and stay in the madrasa. Whereas the selection carried out by the One Roof Madrasah Alyah Al Azhar Kandangan is not much different from the selection carried out by madrasas in general. The selection should be done really to get superior students to accelerate towards achieving and superior madrasas.

\section{d. Orientation}

Orientation is a period of introduction to the school environment. In the madrasa, it is known as matsama (madrasah student ta taarar). The two madrassas are both carrying out these activities with the aim that students are more familiar with their madrasa environment, more adaptable and proud of their choices.

e. Class Distribution

Class division at Darul Amien Taluk Labak Aliyah Madrasah is based on New class X students are grouped into several groups based on the ability to read the Qur'an and their gender. Good male learners who read Al-Qur'an are grouped into group A, female students who are good at reading Al-Qur'an in group B and students who are not good at reading the Qur'an both male and women are included in group $\mathrm{C}$.

Whereas in the One Roof Al Azhar Kandangan Madrasah Aliyah, there is no class distribution, because the available capacity is only I class and the registrant does not exceed the capacity so that all new students are included in the same class.

Grouping students is usually done based on the similarities that exist in students, namely gender and age, or interests, talents, and abilities. In contrast to this, the Aliyah Darul Madrasa Amien Taluk Labak mobilized its students based on their Qur'anic recitations, this shows the direction of cottage-based madrasas, while the One Atap Al-Madrasah Al Azhar Kandangan has not shown the direction of this 
madrasa, because there are no classifications/classifications which is conducted.

f. Student Development and Development Development of discipline and personality in Darul Amien Taluk Labak Aliyah Madrasah and in the One Roof Madrasah Al Azhar Kandangan together by giving us exemplary and making rules of order to be obeyed.

Regulations on discipline in the Talul Labak Aliyah Darul Amien Madrasah are more detailed than the rules of order in the One-Roof Al Azhar Kandangan Madrasah Aliyah. From the rules of discipline in Darul Aliyah Madrasa Amien Taluk Labak shows and feels the feel of the cottage, while the rules of order in the One Roof Aliyah Al Azhar Kandangan Madrasah do not look like a cottage, but look more like ordinary schools/madrasas.

Table I. Table Styles Achievements of Al Azhar Kandangan

\begin{tabular}{ccccc}
\multicolumn{5}{c}{ One-Stop MA Students } \\
\hline No & $\begin{array}{c}\text { Type of } \\
\text { Achievement }\end{array}$ & Champion & Year & Level \\
\hline I & $\begin{array}{l}\text { Arabic } \\
\text { Speech }\end{array}$ & 2 & 2016 & Districts \\
2 & $\begin{array}{l}\text { English } \\
\text { speech }\end{array}$ & 2 & 2016 & districts \\
4 & $\begin{array}{l}\text { Princess } \\
\text { Arabic } \\
\text { Speech }\end{array}$ & 3 & 2016 & districts \\
& & & & \\
& $\begin{array}{l}\text { Tilawah } \\
\text { Puteri }\end{array}$ & & & \\
\hline
\end{tabular}

Table 2: Achievements of MA Darul Amien Taluk Labak

\begin{tabular}{|c|c|c|c|c|}
\hline \multicolumn{2}{|r|}{ Students } & \multirow[b]{2}{*}{ Champion } & \multirow[b]{2}{*}{ year } & \multirow[b]{2}{*}{ Level } \\
\hline No & $\begin{array}{c}\text { Type of } \\
\text { Achievement }\end{array}$ & & & \\
\hline I & Son's English & $\mathrm{I}$ & $20 I 4$ & Province \\
\hline 2 & Speech & I & 2014 & districts \\
\hline $\begin{array}{l}3 \\
4\end{array}$ & $\begin{array}{l}\text { Son } \\
\text { Calligraphy }\end{array}$ & I & 2015 & districts \\
\hline 5 & Daughter's & I & $20 I 5$ & 1. \\
\hline 6 & English & 1 & 2015 & districts \\
\hline 7 & Speech & I & 2015 & districts \\
\hline 8 & Son Arabic & 2 & 2016 & Province \\
\hline IO & MTQ & 3 & 2016 & Province \\
\hline & $\begin{array}{l}\text { Tilawah Putri } \\
\text { Read the }\end{array}$ & 3 & 2016 & Province \\
\hline & Book of Fiqh & 2 & 2016 & Province \\
\hline & $\begin{array}{l}\text { Read the } \\
\text { Book about } \\
\text { the Date }\end{array}$ & 3 & 2017 & Province \\
\hline & Reading the & & & \\
\hline & Interpretation & & & \\
\hline
\end{tabular}

\begin{tabular}{c}
\hline Book \\
Read the \\
Book of \\
Morals \\
Read the \\
Book of \\
Jurisprudence \\
\hline
\end{tabular}

Here's a picture of the cottage based management framework :

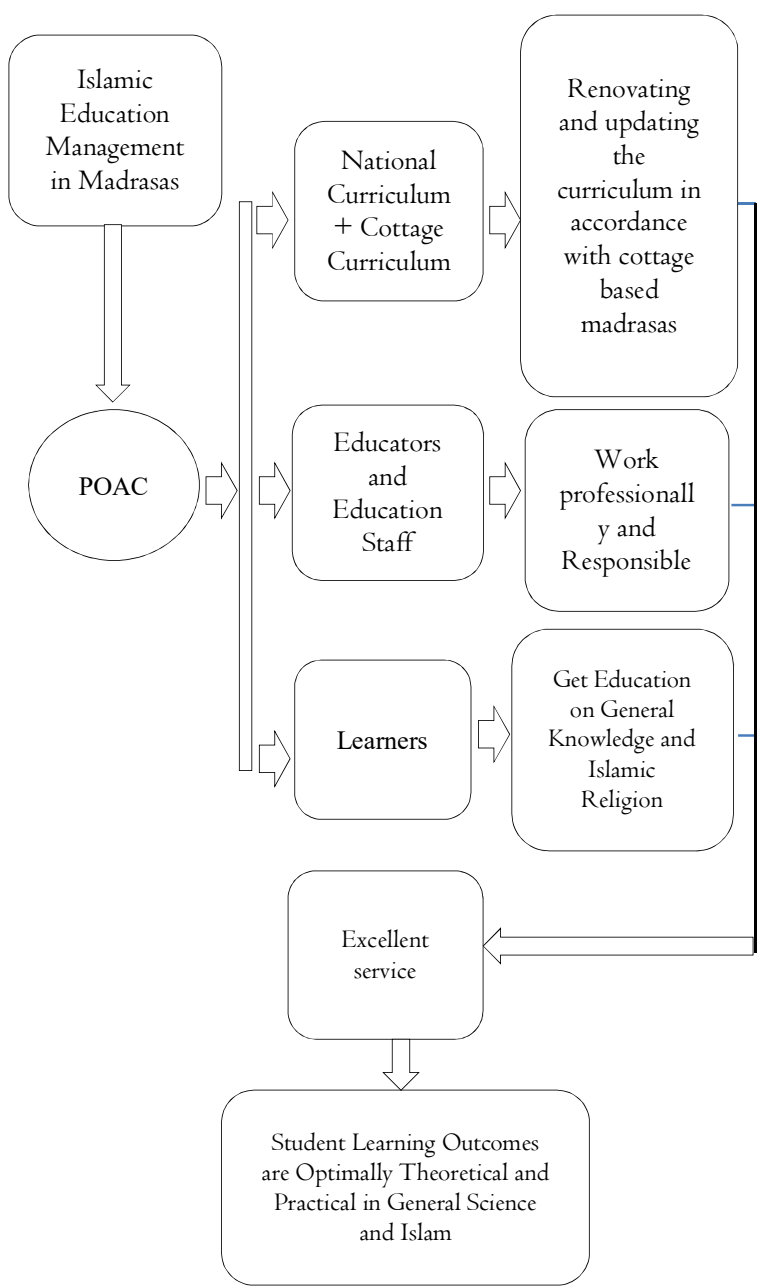

Figure I. Cottage Based Management Framework

\section{Conclusion and Recommendation}

Cottage based management for two Aliyah Madrasahs that are the object of this research has done curriculum management, management of educators and education staff, and management of students so that Darul Amin Teluk Labak Madrasah is able to develop and compete in accordance with the development of the One Roof Al Azhar Kandangan so that the future will be better prepared to face all challenges. 


\section{Acknowledgement}

Authors thank to Lambung Mangkurat University for facilitating and supporting this research.

\section{References}

Alamsyah., Aslamiah., Muhyani, R. (2019). School Based Management Implementation To Improve School Quality Of Multi Sites Study In Sdn Alalak Selatan 2 And Sdn Alalak Selatan 4 Banjarmasin City. International Journal of Scientific Development and Research (IJSDR), 4(I): I-5.

Aslamiah. (20I5). Hubungan Kepemimpinan Transformasional Kepala Sekolah, Kepuasan Kerja, Komitmen Organisai, dan Organizational Citizenship Behavior (OCB) dengan Kinerja Guru Sekolah Dasar Negeri di Kota Banjarmasin. Disertasi, Program Studi Manajemen Pendidikan Pascasarjana Universitas Negeri Malang.

Halim, A. (2005). Manajemen Pesantren. Yogyakarta: Aksara Pelangi.

Normianti, H., Aslamiah, Suhaimi. (2019). Relationship Of Transformational Leaders of Principal, Teacher Motivation, Teacher Organization Commitments With Performance Of Primary School Teachers In Labuan Amas Selatan, Indonesia. European Journal of Education Studies. 5(2): I-9.

Irwan, A. (2003). ManajemenPendidikan. Malang: Universitas Negeri Malang.

Koening \& Samuel. (1957) Mand and Society, the Basic Teaching of Sociology. New York: Borners Van Noble Inc.

Rahmani, M. U., Sulaiman, Aslamiah. (20I9). The Correlation Between Supervision Of School Supervisor And Supervision Of Principal With Teacher Performance In Public Elementary School In Astambul Subdistrict. International Journal of Scientific Development and Research (IJSDR) 4(I): I-9.

Mustari, M., \& Muliawan (20I4). Manajemen Pendidikan. Jakarta: Rajawali Pers.

Nata \& Abuddin (200I). Sejarah Pertumbuhan dan Perkembangan Lembaga-Lembaga Pendidikan Islam di Indonesia. Jakarta: Grasindo.

Kardata, R., Mahrita., Aslamiah. (2018). The Relationship Between Transformational Leadership And Work Motivation With The Teacher's Performance Of Public Elementary School In South Banjarmasin District, Indonesia. European Journal of Education Studies, 5(7): I-9.

Ritzer \& George. (2004). Sosiologi Ilmu Pengetahuan Berparadigma Ganda, trj Alimandan. Jakarta: PT. Raja Grafindo Persada.

Sahrudin, Usman, H., Aslamiah. (2019). Transformational Leadership Contribution
And School Principals' Academic Supervision Towards The Performance Of Public-School Teachers In Gambut District, Banjar Regency. International Journal of Scientific Development and Research (IJSDR), 4(I): I-9.

Suhaimi \& Efendi, N. (20I8). Hubungan Peran Kepala Sekolah dan Sikap Terhadap Profisi Guru dengan Prestasi Kerja Guru SMA negeri di Kabupaten Hulu Sungai Selatan. Jurnal Ilmiah Kependidikan. LENTERA. ISSN: 02I6-7433.

Suriansyah, A. (2018). Contribution On Supervision Of Supervisor, Principals Motivation, Kindergarten Teacher Performance To Improving The Kindergarten Quality In West Banjarmasin, Indonesia. Lambung Mangkurat University.

Suriansyah, Aslamiah \& Sulaiman, (20I4). Strategi Pembelajaran. Raja Grafindo Persada . ISBN 978-979-769-690-0. 